\title{
Sciendo
}

\section{Transforming Georgia's Regulations on Shareholders' Right to Interim Dividend Confronting the European Company Law}

\author{
Ana Tokhadze \\ Faculty of Law, \\ Ivane Javakhishvili Tbilisi State University \\ Chavchavadze Ave. 3, \\ Tbilisi 0179, Georgia \\ Email: ana.tokhadze@tsu.ge
}

\begin{abstract}
The article provides a critical legal analysis of Georgia's regulations on the interim dividend payment and highlights the necessity of proper amendments to comply with European company law. Since having an EU-Georgia Association Agreement signed, the dynamic process of Europeanization has put various legislative changes on the agenda, which also regard shareholders' proprietary rights. This article briefly gives a novel insight into the distribution of interim dividends from a comparative point of view. It suggests the possibly scrutinized coverage of the legal preconditions along with liability consequences for the interim dividend declaration from the perspective of both shareholders and joint stock companies in Georgia. The article emphasizes the structure of the corporation, which naturally bedrocks the potential conflict of interests between the shareholders and creditors. The topic also endorses questioning Georgia's rules on capital maintenance in relation to the interim dividend distribution. Hence, the study reveals prevailing regulatory lapses and makes pertinent recommendations on the alignment of the financial interests of those mentioned. Last but not least, the article exposes how directors on the credible basis of their fiduciary duties are assigned to divert assets of the corporation since their rationality in decision-making is expected to meet the best interests of the company.
\end{abstract}

Keywords: capital maintenance rule, Georgian company law, interim dividends, shareholders' rights 


\section{Introduction}

The protection of shareholders' property rights has always appealed to the academic circle. Admittedly, recent literature highlights the substantiality of the topic (Bratton, 2017; Hill, 2015). As some authors now claim, individual shareholders have transformed into professional and institutionalized funds, which provides comprehensive controlling mechanisms and duties on their part (Cheffins, 2019, pp. 6, 312-314; Magnier, 2017, pp. 114-118). Yet, contemporary European company law renders legal mechanisms at shareholders' disposal for their enhanced participation in corporate governance (Commission Implementing Regulation 2018/1212). Similarly, contemporary Georgian law is on the beam and has the same inclination concerning the shareholders' protection.

Georgian law belongs to the Continental-European family of law. Since the 1990s, well-entrenched cooperation between Georgia and the EU has served as a solid ground for the Europeanization of Georgian law (Chanturia, 2010, pp. 157-158). The political consent expressed through the EU-Georgian Association Agreement allows trichotomy in the levels of the development of Georgian corporate law, according to which the third phase tips balance in favor of the Europeanization of the field (Burduli et al., 2016, pp. 1-10). While there is always a vivid linkage between the politics, economy, and legal regulations, throughout this challenging process, Georgian law is still ascribed to the chain of plausible transformations (Chochia \& Popjanevski, 2016, pp. 198-199, 205-206; Chitashvili \& Zarandia, 2019, pp. 141-142). Amongst several legal updates concerning corporate capital structure, other topics such as amplification of social responsibility, shareholders' long-term engagement have risen to prominence (Tokhadze, 2017). In speaking of the interim dividends, the premise of the article is to bridge shareholders' shortterm economic interest and the corporation's financial viability. The focal point is to give remarks on achieving sufficient interim payout policy in respect to capital maintenance rules. In general, managerial authority is eligible for administrative decisions which might damage the good standing of a corporation's economic climate. Directors often defer to dominant shareholders for which the company might reflect adversely. This may jeopardize the financial aptitude to satisfy creditors or to further business activities. For that purpose, the last part of the article briefly addresses liability consequences for unlawful distribution. 
At the outset, the study examines Georgia's regulations on the distribution of interim dividends in compliance with the EU company law. The article supports the idea of exercising shareholders' property rights based on the capital maintenance concept. The article analyzes legal preconditions for interim dividend distribution. It assesses the level of legal protection that serves to safeguard those who might be aggrieved by an impermissible distribution. Hence, the research aims to address the following questions: (a) To what extent are Georgia's regulations compliant with the EU company law, and do those regulations adhere to the concept of capital maintenance? (b) Do Georgia's rules on interim distribution provide decent protection for the creditors and shareholders? (c) Does Georgian law define distributable assets and relevant legal preconditions for the interim dividend payment? (d) How should the law address the interim dividend distribution?

Georgian corporate law should abide by the standards on capital maintenance and distribution rules of the European company law. Thus, a comprehensive doctrinal study calls for a comparative analysis. Considering the format, the article ostensibly accommodates theoretical rather than empirical deliberation.

\section{Legal preconditions for exercising the right to interim dividends}

Since 2008, Georgian Law on Entrepreneurs (GLE) has adopted the rather liberal US provisions, which backbones exclusion of mandatory articles on the minimum legal capital for both private and public corporations ${ }^{1}$ (Burduli, 2010, pp. 93-96). Dividend-related issues beget from the loose regulations from which stems a free conveyance of corporate profits. The chapter makes an effort to display the discrepancies between the EU and Georgian regulations concerning the interim dividend payment and capital maintenance rules.

1 Except for banks, insurance, and brokerage companies. 


\subsection{Corporate distribution: a presumption of profit allocation}

As some authors suggest, modern-day, giant corporations miraculously manifest the tendency of "capitalism without capital" (Haskel \& Westlake, 2018). Yet, living in the era of intangible and virtual reality, the formation of capital is still an essential segment of incorporation. As a result, European law envisages stringent rules on forming or maintaining the capital which serves as a harbor for the financial sustainability of public corporations (De Luca, 2017, pp. 29-31). Whilst debt financing may also set up share capital, dividends must not be paid from funds other than internal distributable profits. This is where the presumption instead of an obligation of profit distribution comes into play. Otherwise, a corporation would have indebted itself before the shareholders. Some authors emphasize the modern tendency of public corporations refraining from dividend distribution, hence the sale of shares and "decent" leave, in a financial sense, is the only return opportunity available for shareholders (Eisenberg \& Cox, 2011, pp. 1391-1392). Yet, in closed corporations, this can be an issue, especially for the minorities and preferred stockholders. This is why in closed companies, those lacking an easy exit right are equipped with a wider range of control and voice rights (Bainbridge \& Henderson, 2016, p. 58) or with the sell-out right. Thus, to date, share buybacks are a way more common form of value return to shareholders (Ferran \& Chan Ho, 2014, p. 202). The latter is likewise based on capital maintenance rules.

In general, once having contributed the subscribed shares, shareholders exercise their rights on a pro-rata basis equivalent to the consideration ${ }^{2}$ paid (Burduli, 2010, pp. 355-359, 366). Georgian law enshrines the principle of equal treatment, but allows conferring differed rights irrespective of the amount of contribution; moreover, shares are placed regardless of the full payment received by the company (GLE, Art. 3.9 \& 59.1). Under Georgian law, no restrictions on interim or annual distribution apply in the latter case, except for share redemptions. The so-called EU Capital Directive (Council Directive 2012/30/EU), which is a crux of European company law, has been repealed and codified by the Council Directive 2017/1132 (hereafter, Directive). Ever since it has been harmonizing national laws on the incorporation and capital of public limited liability companies, and the restated version still aims at safeguarding shareholders and creditors (Gervan, 2014, pp. 4-8). Despite the criticism for the high costs of capital protection, it assures equal

2 Should the consideration be other than cash, rendering work, or delivering service. Moreover, Georgian law prescribes no time limit on full payment. 
treatment and shareholders' share value against the dilution through the issuance of share for full par value (Grudmann, 2012, pp. 208-212). The Directive embodies a wider sense of corporate distribution, which is defined as dividends and any interest paid to shareholders (Council Directive 2017/1132, Art. 56.4). Yet, it restricts the so-called nimble dividends, which usually can be paid out of current net profits instead of surplus, when the deficit occurs in the account from which the dividend is to be distributed (De Luca, 2017, p. 175). To some degree, sufficient dividend policy provides the shareholders' legal protection as agency costs are relatively reduced due to the managerial obligation to keep the business records (Ferran \& Chan Ho, 2014, p. 206). Georgian law does not define the corporate distribution; neither does it provide an eligible amount for funding annual and interim payment.

\subsubsection{Annual and interim dividends}

Dividends are to be paid at the end of the fiscal year (annually) or during the fiscal year (interim, extraordinary dividends). No payment can be made on treasury shares (Pinto \& Branson, 2018, p. 75). With due regard to common interest and equal treatment, directors propose which class of shareholders are to receive dividends (French, 2017, p. 287). Shareholder's claim to dividend arises upon the decision on a distribution. Since 2015, Georgian law allows interim dividends for only LLCs and joint stock companies. The rule remains silent on the frequency of interim distributions, which interprets itself as a possibility to make the payment monthly, should the relevant profit be available. Even though frequent interim dividends may be attractive to some shareholders, one may doubt creditors' protection without legal strive to impose economically reasonable restraint on profit allocation. Despite the traditional regularity of dividends, in those companies of limited duration, shareholders may also agree on the "one-shot" dividend, allowing distribution only in the case of winding-up (Davies, 2010, pp. 75-76).

\subsubsection{Forms of dividend}

If the corporate bylaw allows, dividends can be paid out other than in cash, e.g., share dividends, property dividends (French, 2017, p. 287). The non-cash dividend is usually auspicious due to the reduced costs and a high probability of selling it once received. Bonus share is a wholly or partially paid new share, issued through transferring profits to a share account for which share premium account may also be used (Talbot, 2016, p. 198). It does not provide asset distribution to the shareholders and 
rather enables obtainment of additional, authorized, yet unissued share. Hence, the net asset is capitalized in the corporate funds, which helps to expand shareholders' financial interest. This will enhance the remaining shareholders' share value (Talbot, 2016, p. 403). Some authors confirm that payment of dividends in cash at some point deprives the company's share value (Sasso, 2013, p. 131; Ferran \& Chan Ho, 2014, pp. 203-204). Accordingly, capitalization should positively affect not only the share but also the general value of the company. Another option is to transfer profits to capital redemption reserves on canceling redeemable shares (French, 2017, p. 287). Georgian law permits any form of dividends made on an annual or interim base.

\subsection{The decision of an authorized corporate body}

Corporations observe certain legal procedures and information accountability when paying dividends. As a pertinent study suggests, the flexibility of Georgia's regulation on interim payment persists questioned (Jugheli \& Nadaraia, 2013), which is quite true. Both annual and interim dividends are paid within the period envisaged through the bylaw, although without exceeding the mandatory nine months from the date of shareholders' approval (GLE, Art. 8.2). Shareholders' meeting may depart from the amount proposed by the management, yet, it happens to carry the only authority to resolve upon interim dividends, which fails to be cost-efficient for being rather intricate. Foreign laws accommodate relaxed procedures by conferring interim distribution power to the directors (Eisenberg \& Cox, 2011, pp. 1387-1388; Forde \& Kennedy, 2017, p. 299). Even though Georgian law treats dividend distributions in the same procedural manner (GLE, Art. 57), when employing interim distribution, management is not obliged to submit interim accounts and financial reports.

\subsubsection{Legal preconditions of decision-making}

\subsubsection{Capital maintenance rule}

As argued, legal capital rules are often doubted on the part of creditor protection (Bachner, 2009, p. 94), which is quite a topic of academic dialogue, too (Lutter, 2006). This sub-chapter is not concerned with an assessment of the legal capital concept; rather, it targets capital maintenance from its narrow understanding against improper regulation on interim dividends. 
As understood, capital maintenance is a set of rules regulating value transfer to shareholders without adequate consideration received by the company (Bachner, 2009, p. 101). Generally, distributions are blocked if net assets stand below the legal capital (Talbot, 2016, pp. 403-404). Considering the essence of limited liability (Bainbridge \& Henderson, 2016, pp. 44-46, 5657) and the principle of asset partitioning (Kraakman et al., 2017, p. 110) capital maintenance is more crucial in corporations than in the business partnerships where partners, bearing the full liability, enable their assets to creditors' satisfaction.

Usually, certain theoretical tests estimate the lawfulness of the distribution. Corporate laws use the Insolvency Test along with the Balance Sheet Test, which, if positively passed, deem the corporate distributions lawful and in alignment with the normal course of business (Eisenberg \& Cox, 2011, pp. 1383-1384). Consequently, annual and interim dividends are lawful if the company meets obligations that become due. Moreover, in some cases (e.g., the US law), the dividend may be paid out of surplus created from either net profit or the excess amount paid for the shares as well as from surplus resulted by a revaluation of corporate assets (Pinto \& Branson, 2018, pp. 76-78). European company law primarily applies the Balance Sheet Test, according to which dividends can be paid if the distribution will not cause dilution of the stated capital and undistributable reserve funds (De Luca, 2017, pp. 172-173, 324). In contrast to Georgia's regulation, the Directive elucidates the definition of distributable funds and provides the legitimate amount or limit of corporate distributions (with reference to the latter, the article employs the term 'quantitative requirement'). It sets the minimum standards, so the Member States may adopt the higher criteria. An annual distribution is allowed if the net assets are not or will not become lower than the aggregate of subscribed capital and undistributable reserves (Council Directive 2017/1132, Art. 56.1). The Directive construes that the annual distribution should be less than the aggregate of the amount of profit at the end of the last financial year and any other profits brought forward or drawn from the reserves for this purpose, less any losses brought forward as well as sums placed in undistributable reserves (Council Directive 2017/1132, Art. 56.3). The interim dividends should fall behind the aggregate of total profits for which the annual accounts were drawn up, thus were made since the end of the last financial year and any other profits brought forward or drawn from the relevant reserves, less any losses brought forward as well as sums that are placed in undistributable reserves (Art. 56.5(b)). The Directive meticulously defines annual and interim corporate distributions 
in the scope of quantitative requirements on accessible and undistributable funds. Hence, through the protection of subscribed capital and the reserves created under the law or bylaw, it achieves a reasonable balance of interests.

Georgian law does not examine the availability of financial funds for the interim returns. Indeed, corporate bylaws may be quite expressive in terms of posing restrictions on capital reserves (Burduli, 2010, p. 156). Although the current law does not embrace an efficient shield for preserving the share capital, neither does it require the creation of share premium or legal reserves. Consequently, interim dividends may still be paid via surplus resulting from the frequent revaluation of corporate assets or formal reduction of the share capital. European law allows capital reduction, yet limited to minimum legal capital, and safeguards creditors with the ability to claim immediate payment (De Luca, 2017, p. 176). The Civil Code of Georgia vests creditors with an ability to call for immediate performance of an undue obligation in the event of debtor's insolvency, reduction or failure to submit the security (CCG, Art. 367). Whereas insolvency, as commented, stands for a serious loss or significant reduction of profits, too (Chanturia et al., 2019). In line with GLE, directors must declare the case of probable or actual insolvency without culpable delay, no later than 3 weeks from the event (GLE, Art. 9.9), otherwise, they risk incurring liability for failing to disclose financially critical information (Bachmann et al., 2016, p. 169). Reasonably, capital maintenance rules do not grant protection during the insolvency, but rather prior to that. As the Directive ascertains, any reduction, except under the court order, in subscribed capital is to be published per Member States' laws (Council Directive 2017/1132, Art. 58.1). Contrary to Georgian law, in the event of a serious loss or reduction of capital, creditors should be notified and a shareholders' meeting should be held to come up with an appropriate solution (Gervan, 2014, p. 24). Thus, throughout the time mens legis of GLE has become oblivious to the capital maintenance concept and creditors' protection.

The Dividend Reinvestment Plan (DRIP) raises capital at the lowest price by investing dividends upon the single shareholder's contest for purchasing the company's shares (Forde \& Kennedy, 2017, p. 300). This eventually creates creditors' extra protection. The lawfully administered reinvestment of net profits is compulsory even if the minorities stand against it. Yet, participating in the DRIP is optional, once decided on dividend declaration. 
Transforming Georgia's Regulations on Shareholders' Right to Interim Dividend Confronting the European Company Law

\subsubsection{Financial disclosure}

The Directive stipulates the imperative duty of financial accountability (Council Directive 2017/1132, Art. 56.5(a)). Distributions are to be justified by reference to the initial, interim, and annual accounts promptly, but in difference to the annual account, an interim one does not require auditor's report (French, 2017, p. 291). Moreover, companies are encouraged to provide condensed balance sheets and cash flow data along with an interim financial statement, which displays significantly less information, which is still enough to illustrate sales or gross revenue, income taxes, cumulative income for each period (Meyers, 2013, pp. 430-432). Like the EU, Georgia complies with IFRS standards (Forde \& Kennedy, 2017, p. 566). However, Georgian regulations do not impose a duty of drawing up an interim account or submission of any other financial reports before preceding to the declaration of the interim dividends. This can result in hiding financial information relevant for resolution upon interim dividends, and question the permissibility of distribution. Drawing up the interim account does not derive from the direct wording of GLE; rather, as argued, it is implied on the base of rules on annual distributions (Jugheli \& Nadaraia, 2013). Albeit rules on annual accounting insinuate on interim accounts, the law must impose an apparent duty on financial statements. As studied, disclosure requirements significantly reduce agency costs and improve the effectiveness of shareholders' decisions (Kraakman et al., 2017, pp. 38-39). Hence, the vague and elusive regulations on financial disclosure diminish the credibility of the law and make it easier to circumvent it, which fails in contending with agency costs, especially in public corporations where directors monitoring is rather difficult than in closed companies (Bachmann et al., 2014, p. 84).

\subsubsection{Protection of minority shareholders}

As defined by GLE, the dominant shareholder has an actual ability to affect the decision-making process (GLE, Art. 8.3), which does not literally refer to the majority shareholders, but also hints at minorities when exercising their rights. Considering the definition, a minority shareholder is the one who stands fewer chances to influence corporate decisions. Hence, when employing decision-making on dividend distribution, this elucidation includes a preference of shareholders with no voice rights as one of them. Some authors picture shareholders and directors as the yin and yang of corporate law, whereas the former is often considered as a quasi-regulator as well (Hill, 2015, pp. 54, 61-68). Directors carry fiduciary duties before the common shareholders; while not necessarily to preference ones (Sasso, 
2013, p. 132). Yet, in this particular case, contracting for anti-dilution provisions or acquisition of convertible security into a common share would remedy the situation (Sasso, 2013, pp. 132-135). While some shareholders enjoy the incentive on "free ride" and benefit from the activist shareholders' actions (Davies, 2010, p. 131), the diverse financial interests may run them afoul of each other. For that, as a last resort, corporate laws usually apply forced purchase rules on squeeze-out and sell-out, along with other protective devices. As the GLE prescribes, at certain legal circumstances related to majorities' state of shareholding, on reasonable grounds the minority shareholders may be dismissed at the fair price (GLE, Art. 534). However, under the current law, there is no sell-out opportunity for the sake of minorities. Thus, the primary source of protection is the law, thereafter a contractual remedy through the specific provisions of the shareholders' agreement. This compartment holds minority shareholders in general rather than as a holder of a particular class of share.

Given Georgian law, the majorities direct dividend policy since the shareholders' meeting with a simple majority resolve upon distribution. Contrary to the US model and separation of ownership and control, dispersed ownership (Makharoblishvili, 2015, pp. 68-75) is not the highlight of Georgian corporate governance. Frequently, dominant shareholders misuse managerial positions. If provided by the bylaw, they may get the participation right in the net asset. This leads to the risk of unfair prejudice against minorities when the majorities get the salaries and by reserving the dividends, they eagerly make minorities exit the corporation. Current regulations allow the share repurchase under two alternative conditions, those being: (a) if the shareholders meetings' resolution substantially aggrieves member's interest; (b) in the case of the restructuring or reorganizing the corporation (GLE, Art. 531). Even though a majority shareholder is liable for misconduct and misuse of the dominant position, the lawsuit is an expensive and protracted solution here. Although there are also some cases of financially driven minority shareholders abusing their duties, too (Conac, 2017, p. 371). Interestingly, if no mandatory or other reserves are available for purposes other than distributing to the shareholders, the Swedish law permits a minority holder (1/10) to request payment of the dividends, yet not more than $5 \%$ of equity, from the profit of the financial year available after covering previous losses (Vutt, 2011, p. 38). Some other European countries (e.g., Finland, Germany) also entitle to minorities the right to minimum dividends, which are compulsory and in favor of their protection (Conac, 2017, p. 365). The Supreme Court of Georgia has also highlighted the 
minorities' right to minimum dividends in one of the pivotal decisions and mentioned that Georgian law is void of restrictions on dividend distribution (Decision AS-378-359-2015). The adoption of a similar mechanism may be reckoned reasonable if accompanied by robust rules on capital maintenance and unambiguous requirements on distributable profits.

\section{Liability for improper distribution in brief}

The decision on interim distribution, as discussed above, should meet legal, procedural, and quantitative requirements. Neither the shareholders' authorization nor the wrong accounts are an excuse for misapplication of the profits (French, 2017, p. 291). As in German law, the unlawfulness of the act together with culpability should be satisfied for a claim for the compensation to arise (Bachner, 2009, p. 154). A breach of fiduciary duties, the doctrine of shadow directorship, equitable subordination, and piercing the corporate veil trigger insiders' personal liability (Bachner, 2009, p. 148). The recent decisions of the Supreme Court of Georgia (AS-1158-1104-2014 and AS-13071245-2014) gave currency to the insiders' liability to the third parties and thus, to date it has become a pressing topic for scholarly discussions (Burduli, 2019; Chanturia, 2016; 2006; Magradze, 2017). Nevertheless, the scope of the article allows a brief depiction of the legal consequences for unlawful distributions.

\subsection{The scope of recipient shareholders' liability}

When regarding improper distributions, it is pertinent to note disguised dividends or undervalued transactions between the company and shareholder, which aim at unrevealed profit transfer (Kraakman et al., 2017, p. 191). The concept of disguised dividends is a product of German legal thinking (Fleischer, 2006) and in a way, relates to camouflaged considerations too (Burduli, 2010, pp. 220-226, 233). Hidden distribution ineligibly returns capital to the shareholder. Corporate laws do allow a contractual relationship between the company and its shareholders. Still, an avoidance of disguised dividends insists upon conducting such transactions duly, based on "an arm's length" principle, yet some authors accentuate the need for the subordination of shareholders loans (Bachner, 2009, p. 104; Vutt, 2011, pp. 31-34). As the discussion continues, intentional fusion or a mixture of assets of the company and shareholder will also lift the corporate veil (Bachmann et al., 2014, p. 168). 
GLE upholds only open, unhidden distributions and restricts payment, should it be other than the dividend (GLE, Art. 57). Shareholders must reimburse or return dividends resulting from the deficient allocation of corporate profits (GLE, Art. 57.2). European company law distinguishes bona fide shareholders from those with knowledge of misapplication and it does not compel faithful shareholders to repayment (Council Directive 2017/1132, Art. 57). If the company proves unfaithfulness of the shareholder, severe, personal and full liability is incurred (Art. 57). The underpinnings of the Directive is to avoid a reduction in further investments and protect a shareholder unaware of irregular distribution by laying the burden of proof on the company (De Luca, 2017, p. 174). According to the US corporate law, directors are obliged to pay compensation to bona fide shareholders (Eisenberg \& Cox, 2011, p. 1393), while claiming indemnification from those who received unlawful dividends (Ferran \& Chan Ho, 2014, p. 226). Shareholders indeed bear personal liability towards creditors for active participation in drawing up intentionally inaccurate balance sheets; however, contrary to directors, shareholders are not expected to carry the duty of checkups on financial calculations (Bachmann et al., 2014, p. 168). For this reason, the Directive supports the protection of shareholders without intent or knowledge of wrongdoing.

\subsection{The scope of directors' liability}

Managerial behaviorism considerably affects a corporation's economic aptitude to captivate investors' financial interest. Enhancing shareholder value has always been on the managerial agenda (Cheffins, 2019, pp. 367-370; Magnier, 2017, pp. 138-139). In the German legal system, the directors' actions are not culpable until they remain within the limits of the law, Sorgfaltspflicht (Bachner, 2009, p. 155). As emphasized, they owe duties and liability before the company, its members, in some cases, to the third parties (Burduli, 2019, pp. 52-57). Duty of loyalty, which in most cases occurs due to the conflict of interest, requires directors to act in the best interest of the corporation (Pinto \& Branson, 2018, p. 241; Chanturia, 2006, pp. 307-309). Without shareholders' consent, directors are restricted to benefit from the company's assets (Chanturia, 2006, p. 303; Forde \& Kennedy, 2017, p. 179). If the breach of duty for the mischievous conduct through the unreasonable managerial overconfidence is discovered, directors face the liability for damages and return of benefits (Bachmann et al., 2014, p. 115). In such cases, they have to provide evidence on proper decision and permissibility of transfers, including the hidden payments (Bachmann et 
al., 2014, pp. 164-165). Although in certain scenarios, directors incur partial liability on the grounds of technical non-compliance to rules on the distribution (Ferran \& Chan Ho, 2014, p. 224). Georgian law construes the director's and supervisory board's joint, severe, and personal liability for unlawful distribution, which may not be waived by the shareholders' meeting (GLE, Art. 57.2). Despite loose regulations on capital maintenance, Georgian law attempts to avoid excessive or hidden distribution through financial accountability and fiduciary duties. In the absence of statutory obligation on filing interim accounts for the interim distribution, the aforementioned does not suffice, especially in public corporations. Classical studies portray agency problems as the main concern of corporate law, which also involves contractual creditors (Easterbrook \& Fischel, 1991, pp. 34-35, 90-94; Kraakman et al., 2017, pp. 29-31). Directors act as guardians of the minorities and third parties (Bachmann et al., 2014, p. 88). For this very reason, some European countries (e.g., France) support directors' liability and envisage their general duty of care towards the creditors while preserving the business judgment rule in place (Bachmann et al., 2014, pp. 101-104). Creditors' financial interests are influenced due to the inflicted losses. Serving as protection, they exercise the right on direct compensation from the director and shareholders receiving unlawful distributions if the company has not satisfied their due claims (GLE, Art. 57.2). This reflects a coherent ramification of an agency relationship to which Georgian law corresponds accordingly.

\section{Concluding remarks}

For the sake of recap, the following remarks addressing the research questions are sufficiently specific. The article has shown that Georgian company law on interim dividend distribution is not compliant with the EU regulations. Particularly, the research holds the idea that the architect of a corporate structure naturally creates the need for alignment of financially differed interests. Yet, deregulation has siphoned Georgian corporate law from former mandatory rules on capital maintenance, which according to the provided study is the substantial element in balancing the financial rights. Hence, undeniably, full implementation of the European standards will help to outline the scope of shareholders' right to interim dividends through the enforcement of capital maintenance rules and supporting an explicit balance of related financial claims. The concept of the article is that the decision on 
interim distribution should meet proper legal, procedural, and quantitative requirements. As emphasized in the paper, in contrast to the EU law, Georgian regulation is absent from the clear definition of appropriate distributable profits and to what extent the interim dividends may be permitted. As recommended, Georgian regulations on interim dividends should embrace reasonable legal restraints through the establishment of statutory reserves and placement of limitations on the frequency of interim payments. Due to the deregulation, as presented in this paper, interim dividends may still be paid via surplus resulting from the frequent revaluation of corporate assets or formal reduction of the share capital. Therefore imposing economically reasonable restrictions on profit allocation is highly recommended. As studied, the European company law sets a requirement on interim accounting. The article argues that Georgian law treats annual and interim dividend distributions in the same procedural manner, yet when distributing interim dividends, management is not obliged to submit interim accounts and financial reports. The research confirms that financial accountability is a crucial precondition for the interim distribution, which precludes decisions made on incorrect financial data. Therefore, it is desirable to encourage the adoption of cost-efficient procedures on resolving power upon the interim distribution as well as setting quantitative requirements and mandatory rules on filing interim accounts or other financial statements. This would strengthen the protection of minority shareholders and creditors. As pointed out in the last section of the article, protection of minority shareholders and creditors is left upon the fiduciary duties, which if forsaken, insiders risk to suffer liability consequences. Yet, as endorsed, the ramification of agency relationship justly allows satisfaction of creditors' claims directly from insiders.

The research argues that directors often make an effort to maximize the majority shareholders' value and keep them content. Such an approach may endanger not only the creditors but the minority shareholders and potential investors as well. Nowadays, Georgian law is not familiar with the sell-out opportunity. The implementation of rules on decent exit rights and incentives on minimum legal dividends would profoundly favor the minorities' protection. However, it is important to observe a delicate balance of the conferred rights and duty of exercising those in good faith, which is indeed an interesting topic for further research. 
Transforming Georgia's Regulations on Shareholders' Right to Interim Dividend Confronting the European Company Law

\section{Acknowledgements}

The research for the article was conducted in the framework of the Dora Plus Scholarship with the financial support of the European Regional Development Fund and the Republic of Estonia and under the scientific supervision of Hon.-Prof. Dr. h.c. Tanel Kerikmäe, LL.M. (Helsinki) at Tallinn University of Technology.

Ana Tokhadze is a doctoral student and academic assistant at the Faculty of Law, Ivane Javakhishvilli Tbilisi State University (Georgia). Under the supervision of Prof. Dr. Dr. h.c. Lado Chanturia, Judge of the European Court of Human Rights, she is conducting research for the thesis entitled Shareholders' Property Rights and Capital of the Corporation. As a doctoral student, she has provided research activities in European educational and research institutions, including Tallinn University of Technology, Max Planck Institute for Comparative and International Private Law, the European University Viadrina.

\section{References}

Association Agreement between the European Union and the European Atomic Energy Community and their Member States, of the one part, and Georgia, of the other part (2014), OJ L 261, 30.8.2014.

Bachmann, G.; Eidenmüller, H.; Engert, A. \& Fleischer, H. (2014), Regulating Closed Corporation. European Company and Financial Review, Berlin \& Boston: De Gruyter.

Bachner, Th. (2009), Creditor Protection in Private Companies. Anglo-German Perspectives for a European Legal Discourse, Cambridge: Cambridge University Press. https://doi.org/10.1017/CBO9780511576553

Bainbridge, St. M. \& Henderson, M. T. (2016), Limited Liability: A Legal and Economic Analysis, Cheltenham: Edward Elgar Publishing.

Bratton, W. W. (2017), 'Corporate law reform in the era of shareholder empowerment,' in B. Choudhury \& M. Petrin (eds.) Understanding the Company, Cambridge: Cambridge University Press, pp. 253-265.

https://doi.org/10.1017/9781316536384.013 
Burduli, I. (2010), Foundations of Corporate Law (On the Basis of German and Georgian Law) [in Georgian], Tbilisi: Meridiani.

Burduli, I. (2019), 'For the issue of director's liability (attempt at dogmatic understanding),' [in Georgian] My Lawyer, Official Journal of the Georgian Bar Association, no. 2, pp. 46-57.

Burduli, I., ed.; Makharoblishvili, G.; Egnatashvili, D. \& Giguashvili, G. (2016). Development of the Contemporary Georgian Corporate Law (General Aspects of Reform) [in Georgian], Tbilisi: "World of Lawyers".

Chanturia, L. (2006), Corporate Governance and Liability of Directors in Corporate Law [in Georgian], Tbilisi: Samartali.

Chanturia, L. (2010), 'Die Europäisierung des georgischen Rechts - bloßer Wunsch oder große Herausforderung?' Rabels Zeitschrift für ausländisches und internationales Privatrecht, Bd. 74, H. 1, pp. 157-158.

https://doi.org/10.1628/003372510790570056

Chanturia, L. (2016), 'Piercing the corporate veil: the liability of the partner for tax fraud by the corporation (novelty in the case law),' in N. Todua (ed.) Guram Nachkebia - 75 [in Georgian], Tbilisi: Meridiani, pp. 406-417.

Chanturia, L., ed. et al. (2019), Commentary on Georgian Civil Code, General Part of Law of Obligations [in Georgian], III Book, Tbilisi: TSU, GIZ, USAID, EMWI.

Cheffins, R. B. (2019), The Public Company Transformed, Oxford: Oxford University Press.

Chitashvili, N. \& Zarandia, T. (2019), 'Fragments of Europeanization of Georgian property law and law of obligations in the context of reception of German law,' Baltic Journal of European Studies, vol. 9, no. 1(26), pp. 141-142. https://doi.org/10.1515/bjes-2019-0008

Chochia, A. \& Popjanevski, J. (2016), 'Change of power and its influence on country's Europeanization process. Case study: Georgia,'in T. Kerikmäe \& A. Chochia (eds.) Political and Legal Perspectives of the EU Eastern Partnership Policy, Cham: Springer International Publishing, pp. 197-210.

https://doi.org/10.1007/978-3-319-27383-9_13.

Civil Code of Georgia (1997), no. 786, Parliamentary Gazette, 31.

Conac, P. -H. (2017), 'The shareholders' duty not to abuse rights,' in H. S. Birkmose (ed.) Shareholders' Duties, Netherlands: Kluwer Law International B.V., pp. 363-375.

Commission Implementing Regulation 2018/1212 laying down minimum requirements implementing the provisions of Directive 2007/36/EC of the European Parliament and of the Council as regards shareholder identification, the transmission of information and the facilitation of the exercise of shareholders rights, $O J$ L 223, 4.9.2018, pp. 1-18. 
Transforming Georgia's Regulations on Shareholders' Right to Interim Dividend Confronting the European Company Law

Council Directive 2017/1132 relating to certain aspects of company law (Codification), OJ L 169, 30.6.2017, pp. 46-127.

Davies, P. (2010), Introduction to Company Law, 2nd ed., Oxford: Oxford University Press. https://doi.org/10.1093/he/9780199207763.001.0001

Decision of the Supreme Court of Georgia no. AS-1158-1104-2014, 6.5.2015.

Decision of the Supreme Court of Georgia no. AS-1307-1245-2014, 6.5.2015.

Decision of the Supreme Court of Georgia no. AS-378-359-2015, 21.12.2015.

De Luca, N. (2017), European Company Law, Cambridge: Cambridge University Press.

Easterbrook, F. H. \& Fischel D. R. (1991), The Economic Structure of Corporate Law, Cambridge: Harvard University Press.

Eisenberg, M. A. \& Cox, J. D. (2011), Corporations and Other Business Organizations, 10th ed., New York: Foundation Press.

Ferran, E. \& Chan Ho, L. (2014), Principles of Corporate Finance, 2nd ed., Oxford: Oxford University Press. https://doi.org/10.1093/acprof:o so/9780199671342.001.0001

Fleischer, H. (2006), 'Disguised distributions and capital maintenance in European company law,' in M. Lutter (ed.) Legal Capital in Europe. European Company and Financial Review-Special Issue, Berlin: De Gruyter Recht, pp. 94-111. https://doi.org/10.1515/9783110926583.94

Forde, M. \& Kennedy, H. (2017), Company Law, 5th ed., Dublin: Thomson Reuters Ireland Limited.

French, D. (2017), Company Law, 34th ed., Oxford: Oxford University Press.

Gervan, D. V., ed. (2014), 'Community rule applicable to the incorporation and capital of public limited liability companies,' in Capital Directive in Europe, Cambridge: Cambridge University Press, pp. 3-52.

Grudmann, St. (2012), European Company Law, 2nd ed., UK: Intersentia.

Haskel, J. \& Westlake, S. (2018), Capitalism without Capital: The Rise of the Intangible Economy, Princeton, NJ: Princeton University Press. https://doi.org/10.1515/9781400888320

Hill, J. G. (2015), 'Images of shareholder - shareholder power and shareholder powerlessness,' in J. G. Hill \& R. S. Thomas (eds.) Research Handbook on Shareholder Power, Cheltenham: Edward Elgar Publishing, pp. 53-72. https:// doi.org/10.4337/9781782546856.00010

Jugheli, G. \& Nadaraia, L. (2013), 'The impact of tax risks on entrepreneurial decisions-intermediate dividend example' [in Georgian], Georgian Business Law Review, vol. 2, pp. 3-11.

Kraakman, R. et al. (2017), The Anatomy of Corporate Law: A Comparative and Functional Approach, 3rd ed., Oxford: Oxford University Press. https://doi.org/10.1093/acprof:oso/9780198739630.001.0001 
Law of Georgia on Entrepreneurs (1994), no. 577, Departments of the Parliament of Georgia.

Lutter, M., ed. (2006), Legal Capital in Europe. European Company and Financial Review-Special Issue, Berlin: De Gruyter Recht. https://doi.org/10.1515/9783110926583

Magnier, V. (2017), Comparative Corporate Governance: Legal Perspectives, Cheltenham: Edward Elgar Publishing.

Magradze, G. (2017), 'For the issue of personal liability of directors/managers and partners/shareholders in a business entity,' Journal of Law, no. 1, pp. 114-129.

Makharoblishvili, G. (2015), General Review of Corporate Governance. Comparative and Legal Analysis [in Georgian], Tbilisi: "World of Lawyers".

Meyers, Ch. H. (2013), Accounting and Finance for Lawyers in a Nutshell, 5th ed., Eagan, MN: West Academic Publishing Co.

Pinto, A. R. \& Branson D. M. (2018), Understanding Corporate Law, 5th ed., Durham, NC: Carolina Academic Press.

Sasso, L. (2013), Capital Structure and Corporate Governance. The Role of Hybrid Financial Instruments, Alphen aan den Rijn: Walters Kluwer International.

Talbot, L. (2016), Critical Company Law, 2nd ed., New York: Routledge.

Tokhadze, A. (2017), 'Enhancement of corporate social responsibility-an analysis from the perspective of economic and sectoral cooperation under the three association agreements,' in A. Tunk, N. Panych \& S. Rieckhof (eds.) Legal Aspects of the EU Association Agreements with Georgia, Moldova and Ukraine in the Context of the EU Eastern Partnership Initiative, Lohmar-Köln: EUL Verlag, pp. 104-111.

Vutt, A. (2011), Legal Capital Rules as a Measure for Creditor and Shareholder Protection, PhD thesis, University of Tartu, Tartu University Press. 